\title{
Effect of Ambient Temperature on Electric Vehicles' Energy Consumption and Range: Model Definition and Sensitivity Analysis Based on Nissan Leaf Data
}

\author{
Paolo Iora ${ }^{1}$ and Laura Tribioli ${ }^{2, *(\mathbb{D})}$ \\ 1 Department of Mechanical and Industrial Engineering, Università di Brescia, via Branze 38, \\ 25123 Brescia BS, Italy; paolo.iora@unibs.it \\ 2 Department of Industrial Engineering, Università di Roma Niccolò Cusano, 00166 Roma RM, Italy \\ * Correspondence: laura.tribioli@unicusano.it
}

Received: 13 December 2018; Accepted: 2 January 2019; Published: 7 January 2019

\begin{abstract}
In this paper, a general quasi-steady backward-looking model for energy consumption estimation of electric vehicles is presented. The model is based on a literature review of existing approaches and was set up using publicly available data for Nissan Leaf. The model has been used to assess the effect of ambient temperature on energy consumption and range, considering various reference driving cycles. The results are supported and validated using data available from an experimental campaign where the Nissan Leaf was driven to depletion across a broad range of winter ambient temperatures. The effect of ambient temperature and the consequent accessories consumption due to cabin heating are shown to be remarkable. For instance, in case of Federal Urban Driving Schedule (FUDS), simplified FUDS (SFUDS), and New European Driving Cycle (NEDC) driving cycles, the range exceeds $150 \mathrm{~km}$ at $20^{\circ} \mathrm{C}$, while it reduces to about $85 \mathrm{~km}$ and $60 \mathrm{~km}$ at $0{ }^{\circ} \mathrm{C}$ and $-15{ }^{\circ} \mathrm{C}$, respectively. Finally, a sensitivity analysis is reported to assess the impact of the hypotheses in the battery model and of making different assumptions on the regenerative braking efficiency.
\end{abstract}

Keywords: electric vehicle; ambient conditions; range estimation; energy analysis; sensitivity analysis; experimental validation

\section{Introduction}

In 2016, the transportation sector was responsible of about one-third of the world's oil demand and, as a consequence, of the total $\mathrm{CO}_{2}$ emissions [1]. Because of the related environmental concerns, in recent years, innovative technologies have been progressively gaining a share in the automotive industry, aiming at both improving the power train conversion efficiency and reducing the dependence on fossil fuels. Solutions are mainly based on the adoption of new vehicle concepts that make use of green energy carriers such as electricity or hydrogen, as in electric or hybrid vehicles [2-4].

In battery electric vehicles (BEVs), the battery remains the most critical component. Battery state-of-health estimations, together with thermal safety issues, are of utmost importance for improving performance, safety, and cost-effectiveness of these vehicles, as they strongly influence driving performance and particularly range per charge $[5,6]$. In fact, the major barrier to large scale adoption of BEVs is the rather low range-typically less than $300 \mathrm{~km}$-compared with classical diesel or gasoline fueled vehicles [7], which causes anxiety among the users [8], especially for the concern of finding a charging station [9]. As a matter of fact, higher ranges can be obtained by increasing battery size and although this affects the vehicle price, consumers may prefer spending more to gain some extra range [10]. 
Besides these problems, light-duty BEVs remain a promising technology and have been extensively investigated in several studies, especially in terms of overall energy consumption and vehicle range estimations [11-17]. Range is clearly affected by vehicle speed; driver's driving style; carried weight; terrain conditions; and all the on-board energy-consuming services such as heating, ventilation, and air-conditioning (HVAC). Therefore, in order to assess the real opportunities of such vehicles, it is necessary to have an extensive knowledge on the influence of real-world usage, which can significantly affect the overall energy consumption and thus the vehicle range. In literature, studies mainly focus on the effect of traffic conditions, accelerations, idling, and braking on vehicle energy consumption [18,19]. Fiori et al. [20] investigated the impact of route selection on the energy consumption of a BEV, using empirical global positioning system (GPS) commute data and traffic micro-simulation data; Maia et al. [21] carried out an analysis to experimentally correlate trip distance, speed, initial battery state of charge, and ambient temperature to energy consumption; Wu et al. [22] investigated the effect of the driver's behavior on the BEV efficiency between in-city driving and freeway driving, providing a general relationship between the measured power of the battery and the measured speed, acceleration, and road slope; and Shankar and Marco [23] reported on energy consumption predictions for BEVs under real-world driving conditions, considering traffic type and congestion.

Nonetheless, energy consumption and vehicle range of BEVs are affected also by varying climate conditions, not only for their direct influence on the electric components operation, but mainly for the increase in the accessory power consumption due to cabin heating, ventilating, and air-conditioning. This aspect becomes critic in cold weather; unlike fossil fuel-powered vehicles, the thermal energy available from the electric motor is not able to meet heating demands in winter and the energy consumption related to heating can significantly affect the vehicle performance in terms of range. Things obviously get worse when the main cabin heating systems are based on electrical resistive heating, rather than a heat pump [24,25], as in the case of the popular Mitsubishi i-MiEV [26] and Nissan Leaf electric cars [27].

In view of the significance of accurate energy consumption estimation, many experimental campaigns have been directed to assessing $\mathrm{BEVs}^{\prime}$ range as climate conditions change [28-31]. Despite that these analyses have contributed the rise of a rich library of information on the effect of auxiliary loads on vehicle range, only a few studies provide analytical estimations on energy consumption related to HVAC systems and most of them imply rather complex models. Kambly and Bradley [32] realized a detailed dynamic vehicle thermal comfort model to evaluate the impact of HVAC loads on BEVs' range, considering ambient conditions and cabin thermal comfort, but the model accuracy requires a number of assumptions and data that may vary significantly from vehicle to vehicle. Hendricks [33] focused their analysis on the energy consumption of the HVAC system itself, not considering the effects on the overall vehicle range. Farrington and Rugh [34] proposed a more straightforward model, showing that the range of BEVs is reduced by about $50 \%$ as a result of cabin cooling as outside temperature vary, but without making any considerations for cabin heating. At the same time, for range evaluation purposes, simplified backward looking models are considered sufficiently accurate, and have the advantages of higher flexibility, lower computational effort, and requiring the knowledge of a smaller number of input data [35].

On the basis of these considerations, in this paper, a general BEV energy consumption model is presented, based on a review of existing approaches on powertrain components modelling, which can be easily calibrated using publicly available BEV data. By characterizing the model on data available for Nissan Leaf, the effect of the ambient temperature on energy consumption and range is investigated.

The paper is organized as follows: in Section 2 the model governing equations are presented, based on state of the art analysis of existing models, particularly focused on Nissan Leaf; in Section 3, the model is validated on data available from an experimental campaign during which the Nissan Leaf was driven to depletion across a broad range of winter ambient temperatures; in Section 4, a sensitivity 
analysis is carried out on the assumptions on the battery model and the regenerative braking efficiency; and conclusions are finally drawn in Section 5.

\section{Model Description}

A quasi-steady backward-looking model for the simulation of BEVs was developed in Matlab ${ }^{\circledR}$, following the approach first proposed by Larminie and Dicks [36] and subsequently adopted and further improved by other researchers [19,37-40]. The proposed model is based on a critical analysis of the main assumptions made in existing models of the different components, aiming at identifying the best compromise between accuracy and the possibility to build up a straightforward and effective tool for the simulation of commercial electric vehicles, whose construction and operating data are often difficult to obtain from car manufactures. To this end, the analysis is particularly focused on the Nissan Leaf, and Table 1 shows the main assumptions adopted in the most relevant up-to-date published Nissan Leaf models. Last column of the table reports the assumptions used in the present study.

In a backward-looking approach, the vehicle follows the velocity specified by the driving cycle so that the power required at the wheels can be determined as a function of the resistance and the inertia forces. The power flow is bidirectional, as shown in Figure 1: electrical energy is drawn from the battery and transformed into kinetic energy during traction, while kinetic energy from the wheels is transformed into electrical energy during braking.

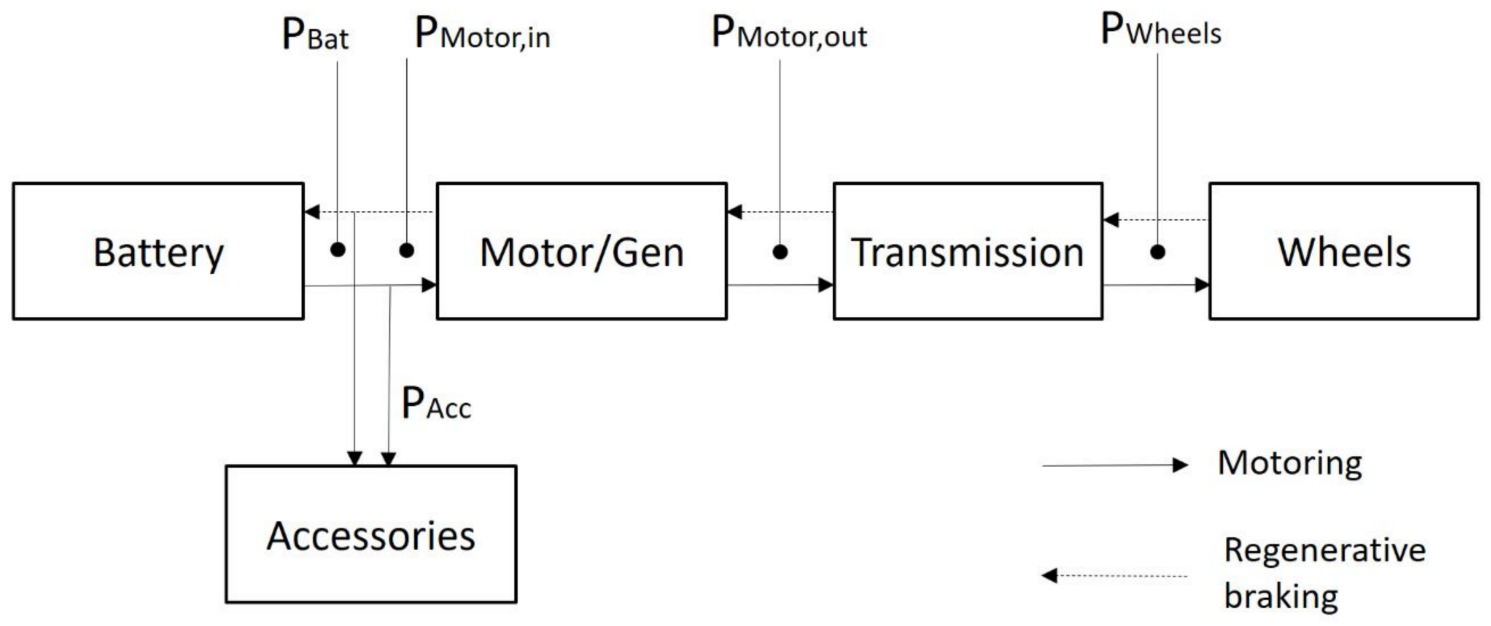

Figure 1. Block diagram of the power flows in the components of the electric vehicle $[36,37]$.

The output of the model is the driving distance obtained after discharging the battery down to a specified value of the state of charge (SOC). The traction power at the driving wheels can be expressed as follows:

$$
P_{\text {Wheels }}=\left[\mu_{r r} m_{v} g \cos \alpha+\frac{1}{2} \rho A C_{d} v(t)^{2}+m_{v} g \sin \alpha+\left(m_{v}+m_{I}\right) a(t)\right] v(t)
$$

where terms in the square brackets represent rolling resistance, aerodynamic drag, grading resistance, and linear acceleration, respectively. According to the authors of [40], $m_{I}$, which represents a fictitious mass taking into account the inertia of rotating components, can be expressed as follows:

$$
m_{I}=m_{c}\left(0.04+0.0025 G^{2}\right)
$$

It should be noted that $P_{\text {Wheels }}$ can be either positive or negative. In the first case, the battery pack provides energy to the motor. In the second case, representative of the regenerative braking mode, 
the energy flows from the wheels to the generator to charge the battery, as shown in Figure 1. Thus, $P_{\text {Motor,out }}$ is expressed by the following:

$$
\begin{gathered}
P_{\text {Motor,out }}=\frac{P_{\text {Wheels }}}{\eta_{\text {tr }}} \text { if } P_{\text {Wheels }}>0 \\
P_{\text {Motor }, \text { out }}=P_{\text {Wheels }} \eta_{t r} \eta_{r b} \text { if } P_{\text {Wheels }}<0
\end{gathered}
$$

where $\eta_{t r}$ is the transmission efficiency and $\eta_{r b}$ is the regenerative braking efficiency, which identifies the percentage of the total braking power that can actually be recovered, as per the following equation:

$$
\eta_{r b}=\frac{P_{\text {Recoverable }}}{P_{\text {Wheels }}}
$$

Several expressions for $\eta_{r b}$ have been proposed, as already reported in Table 1. In the work of [38], all the available regenerative energy is assumed to be returned to the battery as long as the regenerative power is lower than or equal to $20 \mathrm{~kW}$; Genikomsakis and Mitrentsis [37] express $\eta_{r b}$ as a function of the vehicle speed and consider the recoverable power subject to the braking torque limitation of the electric motor/generator. Maia et al. [40] introduce a braking torque reduction factor, a function of some collection of variables that represent the instantaneous driving parameters (acceleration, jerk, road inclination). In the present analysis, the approach proposed by the authors of [1] was applied, where the regenerative braking efficiency $\eta_{r b}$ is assumed to be a function of acceleration (always negative when braking). The following exponential relationship, calibrated on empirical data on regenerative braking energy efficiency for a Chevy Volt vehicle, has thus been used:

$$
\eta_{r b}=\left[e^{\left(\frac{0.0411}{|a(t)|}\right)}\right]^{-1}
$$

Next, the term $P_{\text {Motor,in }}$ (Figure 1) is computed on the basis of the efficiency of motor/generator $\eta_{m}$ :

$$
\begin{gathered}
P_{\text {Motor, in }}=\frac{P_{\text {Motor }, \text { out }}}{\eta_{m}} \text { if } P_{\text {Motor, out }}>0 \\
P_{\text {Motor }, \text { in }}=P_{\text {Motor, out }} \eta_{m} \text { if } P_{\text {Motor }, \text { in }}<0
\end{gathered}
$$

It is worth noting that, although the value of $\eta_{m}$ is a general function of both instantaneous speed and torque of motor/generator, in the present study, the more general approach, proposed by the authors of [37], has been employed, in which the motor/generator efficiency is a piecewise function of the load. The efficiency is finally corrected with a size coefficient that, in the case of the Nissan Leaf motor with a rated power of $80 \mathrm{~kW}$, is 0.988 . The resulting efficiency values employed in this study are reported in Table 2. 
Table 1. Summary of the main assumptions adopted in various Nissan Leaf published models. SOC—state of charge.

\begin{tabular}{|c|c|c|c|c|c|c|c|}
\hline Reference & [37] & [38] & [39] & [40] & [1] & [19] & Assumed Here \\
\hline Nominal battery energy & $24 \mathrm{kWh}$ & $24 \mathrm{kWh}$ & $24 \mathrm{kWh}$ & $\begin{array}{c}\text { Capacity of } 65 \text { Ah times } \\
\text { open circuit voltage as by } \\
\text { Equation (9) with SOC at } \\
\text { nominal conditions }\end{array}$ & - & $24 \mathrm{kWh}$ & $\begin{array}{l}\text { Capacity of } 65 \text { Ah times } \\
\text { open circuit voltage as by } \\
\text { Equation (9) with SOC at } \\
\text { nominal conditions [40] }\end{array}$ \\
\hline Battery efficiency & $95 \%$ & $\begin{array}{c}\text { Based on charge } \\
\text { efficiency of } 85 \% \text { and } \\
R_{\text {int }}=0.11 \Omega\end{array}$ & $\begin{array}{l}\text { Based on round trip } \\
\text { efficiency of } 85 \% \text { and } \\
\qquad R_{\text {int }}=0.1 \Omega\end{array}$ & $\begin{array}{l}\text { Based on round trip } \\
\text { efficiency of } 97 \% \text { and } \\
R_{\text {int }}=\text { as by Table } 3\end{array}$ & $90 \%$ & - & $\begin{array}{c}\text { Based on internal resistance } \\
\text { as by Table } 3 \text { [40] and } \\
\text { Peukert battery model with } \\
k=1.03 \text { [41] }\end{array}$ \\
\hline Rolling coefficient & 0.008 & \multirow{4}{*}{$\begin{array}{l}\text { Vehicle load forces } \\
\text { expressed as function } \\
\text { of vehicle speed }\end{array}$} & 0.008 & 0.007 & $\begin{array}{c}1.75 \times 10^{-3} \\
(0.0328 \mathrm{v}+4.575)\end{array}$ & 0.012 & $\begin{array}{c}1.75 \times 10^{-3} \\
(0.0328 \mathrm{v}+4.575)[1]\end{array}$ \\
\hline Drag coefficient & 0.29 & & $0.28 / 0.29$ & 0.28 & 0.28 & 0.29 & 0.28 \\
\hline Frontal area, $\mathrm{m}^{2}$ & 2.19 & & 2.19 & 2.29 & 2.3316 & 2.27 & 2.3 \\
\hline Air density, $\mathrm{kg} / \mathrm{m}^{3}$ & 1.25 & & - & 1.25 & 1.2256 & 1.2 & Function of temperature \\
\hline Transmission efficiency & 0.97 & 0.97 & 0.97 & 0.83 & 0.92 & $\begin{array}{l}\text { Included in overall } \\
\text { power train } \\
\text { efficiency of } 80 \%\end{array}$ & 0.97 \\
\hline Gear ratio, G & 8.2 & 7.9377 & $7.94 / 8.19$ & 7.937 & - & - & 7.94 \\
\hline Tire radius, $\mathrm{m}$ & 0.316 & 0.315 & 0.316 & 0.309 & - & & 0.31 \\
\hline $\begin{array}{l}\text { Maximum motor } \\
\text { power, } \mathrm{kW}\end{array}$ & 80 & 80 & 80 & 80 & - & - & 80 \\
\hline Motor / generator efficiency & Function of load & $\begin{array}{l}\text { Based on a per-phase } \\
\text { equivalent circuit } \\
\text { electric model }\end{array}$ & $\begin{array}{c}89 \%-96 \% \text { (Motor + } \\
\text { controller efficiency) }\end{array}$ & $\begin{array}{l}\text { Varying between } 85 \% \text { and } \\
95 \% \text { as function motor } \\
\text { torque and speed }\end{array}$ & $91 \%$ & $\begin{array}{l}\text { Included in overall } \\
\text { power train } \\
\text { efficiency of } 80 \%\end{array}$ & $\begin{array}{c}\text { Function of load, according } \\
\text { to authors of [37] }\end{array}$ \\
\hline $\begin{array}{l}\text { Power consumption of } \\
\text { accessories (cabin air } \\
\text { conditioning excluded), W }\end{array}$ & 300 & 180 & 200 & 269 & 700 & 400 & 200 \\
\hline $\begin{array}{c}\text { Vehicle mass } \\
\text { (curb weight), kg }\end{array}$ & - & 1521 & $1498 / 1691$ & 1521 & 1521 & 1521 & 1521 \\
\hline $\begin{array}{l}\text { Vehicle mass including } \\
\text { occupants } \\
\text { (gross weight), } \mathrm{kg}\end{array}$ & 1663 & 1701 & - & 1761 & $1595 / 1640$ & $1601 / 1731$ & 1600 \\
\hline $\begin{array}{l}\text { Fictitious vehicle mass } \\
\text { increase due to the inertia } \\
\text { of rotating components, } \mathrm{kg}\end{array}$ & $0.05 \cdot m_{c}$ & - & - & $m_{c}\left(0.04+0.0025 G^{2}\right)$ & - & $0.03 \cdot m_{c}$ & $m_{c}\left(0.04+0.0025 G^{2}\right)[40]$ \\
\hline $\begin{array}{l}\text { Regenerative braking } \\
\text { model }\end{array}$ & $\begin{array}{l}\text { Speed-dependent } \\
\text { regeneration efficiency; } \\
\text { limit on maximum } \\
\text { generator torque }\end{array}$ & $\begin{array}{l}\text { Limited to maximum } \\
\text { braking power } \\
\text { of } 20 \mathrm{~kW}\end{array}$ & $\begin{array}{l}100 \% \text { regenerative } \\
\text { braking at all } \\
\text { vehicle speeds }\end{array}$ & $\begin{array}{l}\text { Regenerative coefficient } \\
\text { based on a fuzzy } \\
\text { logic model }\end{array}$ & $\eta_{r b}=\left[e^{\left(\frac{0.0411}{\mid a(t))}\right)}\right]^{-1}$ & Not considered & $\eta_{r b}=\left[e^{\left(\frac{0.0411}{1 a(t)}\right)}\right]^{-1}[1]$ \\
\hline
\end{tabular}


Table 2. Motor/generator efficiency [37].

\begin{tabular}{ccc}
\hline \multirow{2}{*}{ Part Load Fraction } & \multicolumn{2}{c}{$\eta_{\boldsymbol{m}}, \%$} \\
\cline { 2 - 3 } & Motor & Generator \\
\hline 0.01 & 58.72 & 56.62 \\
0.02 & 72.24 & 70.63 \\
0.05 & 83.89 & 83.02 \\
0.1 & 88.67 & 88.20 \\
0.2 & 91.28 & 91.04 \\
0.3 & 92.12 & 91.98 \\
0.4 & 92.71 & 92.56 \\
0.5 & 93.31 & 93.14 \\
0.6 & 93.91 & 93.71 \\
0.7 & 94.51 & 94.29 \\
0.8 & 94.43 & 94.74 \\
0.9 & 93.67 & 94.07 \\
1 & 92.91 & 93.41 \\
\hline
\end{tabular}

Still referring to Figure 1, $P_{\text {Bat }}$ takes into account also the power consumed by the accessories as per the following equation:

$$
P_{\text {Bat }}=P_{\text {Motor, in }}+P_{\text {Acc }}
$$

where $P_{A c c}$ is assumed to be a linear decreasing function of the ambient temperature, ranging from a maximum value of $6000 \mathrm{~W}$ at $T_{a m b}=-15^{\circ} \mathrm{C}$ to a minimum value of $200 \mathrm{~W}$ at $T_{a m b}=20^{\circ} \mathrm{C}$, when the HVAC system is turned off.

Given the value of $P_{B a t}$, the input or output current flows, occurring during battery charging (regenerative braking) and discharging (motoring), can be evaluated by solving the battery equivalent circuit according to the following Equation (8) [36,40]:

$$
\begin{gathered}
I=\frac{E-\sqrt{E^{2}-4 R_{\text {int }} P_{\text {Bat }}}}{2 R_{\text {int }}} \text { if } P_{\text {Bat }}>0 \\
I=\frac{-E+\sqrt{E^{2}-4 R_{\text {int }} P_{\text {Bat }}}}{2 R_{\text {int }}} \text { if } P_{\text {Bat }}<0
\end{gathered}
$$

where $R_{\text {int }}$ and $E$ are the internal resistance and the open circuit potential, respectively. According to the authors of [40], $E$ can be expressed as a function of the SOC as per Equation (9), while the values of $R_{i n t}$ in charging and discharging can be defined as a piecewise function of SOC, as reported in Table 3 .

$$
E=367.7789-\frac{3.2085}{S O C}-14.3522 S O C+1.138 \ln (S O C)+6.0957 \ln (1-S O C)
$$

Table 3. Battery internal resistance.

\begin{tabular}{ccccccccccc}
\hline SOC & $\mathbf{0 . 1}$ & $\mathbf{0 . 2}$ & $\mathbf{0 . 3}$ & $\mathbf{0 . 4}$ & $\mathbf{0 . 5}$ & $\mathbf{0 . 6}$ & $\mathbf{0 . 7}$ & $\mathbf{0 . 8}$ & $\mathbf{0 . 9}$ & $\mathbf{1 . 0}$ \\
\hline$R_{\text {int }}$ - charging, $\Omega$ & 0.0830 & 0.0830 & 0.0892 & 0.0997 & 0.1051 & 0.0894 & 0.0919 & 0.1135 & 0.1026 & 0.0997 \\
$R_{\text {int }}$ - discharging, $\Omega$ & 0.0620 & 0.0620 & 0.0587 & 0.0691 & 0.0593 & 0.0928 & 0.0906 & 0.0664 & 0.0892 & 0.0250 \\
\hline
\end{tabular}

In addition to the efficiency loss due to the heat dissipated by the internal resistance, a battery charge efficiency based on the Peukert model $[37,41]$ is included in the analysis, where the Peukert capacity $C_{p}$ is given by the following:

$$
C_{p}=I^{k} t
$$

In Equation (10), $k$ is the Peukert constant of the battery, which in the case of the Li-ion battery, according to the authors of [41], can vary between 1 and 1.08. Here, $k=1.03$ has been chosen as a result of the model validation, which will be discussed later in Section 3. Terms $I$ and $t$ are the rated current and the rated discharging time, respectively. These values can be easily obtained from the discharge 
characteristic curve of the Nissan Leaf battery available from [42]. In fact, given the battery capacity $C=65 \mathrm{Ah}$, by substituting the rated discharge current $I=0.3 \mathrm{C}=19.5 \mathrm{~A}$ and the corresponding rated discharging time $t=3.33 \mathrm{~h}$ into Equation (10), the obtained result is $C_{p}=71.1 \mathrm{Ah}$.

Then, at each time step $\Delta t_{i}$, the charge removed during discharging or added during charging is computed as follows:

$$
\begin{aligned}
& \Delta C R_{i}=I_{i}^{k} \Delta t_{i} \text { if } P_{\text {Bat }}>0 \\
& \Delta C R_{i}=-I_{i} \Delta t_{i} \text { if } P_{\text {Bat }}<0
\end{aligned}
$$

so that $S O C_{n}$, after $n$ time steps, can be obtained as follows:

$$
\operatorname{SOC}_{n}=1-\frac{\sum_{i=1}^{n} \Delta C R_{i}}{C_{p}}
$$

\section{Model Validation}

The model is validated on the data recorded through the experimental campaign reported in the work of [27], where the Nissan Leaf was driven to depletion across a broad range of ambient temperatures occurring in Winnipeg, MB, Canada, during winter. Several travelling ranges were measured in routes with speed limits of $50,60,70$, and $80 \mathrm{~km} / \mathrm{h}$, resulting in an average speed, including all stoppages, of $35-40 \mathrm{~km} / \mathrm{h}$.

As the driving cycle data employed in the experimental analysis were not available, the aforementioned driving conditions were reproduced with two standard driving cycles of similar topology: Federal Urban Driving Schedule (FUDS) $\left(v_{\max }=91 \mathrm{~km} / \mathrm{h}, v_{a v}=32 \mathrm{~km} / \mathrm{h}\right)$ and Simplified FUDS (SFUDS) $\left(v_{\max }=87 \mathrm{~km} / \mathrm{h}, v_{a v}=31 \mathrm{~km} / \mathrm{h}\right.$ ). FUDS, developed into the Federal Urban Driving Schedule, is one of the most well-known standard driving cycles, based on real urban traffic flows in Los Angeles. SFUDS is a simplified version of this cycle, commonly employed for the analysis of electric vehicles performance $[36,43]$. Compared with FUDS, it is characterized by a similar average speed, the same proportion of stationary time, and the same maximum acceleration and braking, thus providing generally very similar results when used for simulating vehicle range. The analysis was also extended to two additional driving cycles, namely the New European Driving Cycle (NEDC) $\left(v_{\max }=120 \mathrm{~km} / \mathrm{h}, v_{a v}=32 \mathrm{~km} / \mathrm{h}\right)$ and FIGE cycle, named after the German FIGE Institute, $\left(v_{\max }=91 \mathrm{~km} / \mathrm{h}, v_{a v}=59 \mathrm{~km} / \mathrm{h}\right)$, which differ from the urban nature of the reference experimental data. In fact, NEDC consists of four repeated ECE-15 urban driving cycles and one extra-urban driving cycle, while different driving conditions are represented by FIGE, which includes urban, rural, and motorway driving. All the considered driving cycles are reported in Figure 2. Simulations are carried out considering an external ambient temperature ranging from -15 to $+20^{\circ} \mathrm{C}$. Accessories consumption varies linearly from $6000 \mathrm{~W}$ at $-15^{\circ} \mathrm{C}$ with heating at full power to $200 \mathrm{~W}$ at $20^{\circ} \mathrm{C}$ when the heating is switched off. Simulations start with battery fully charged and end at $S O C=0.1$. 

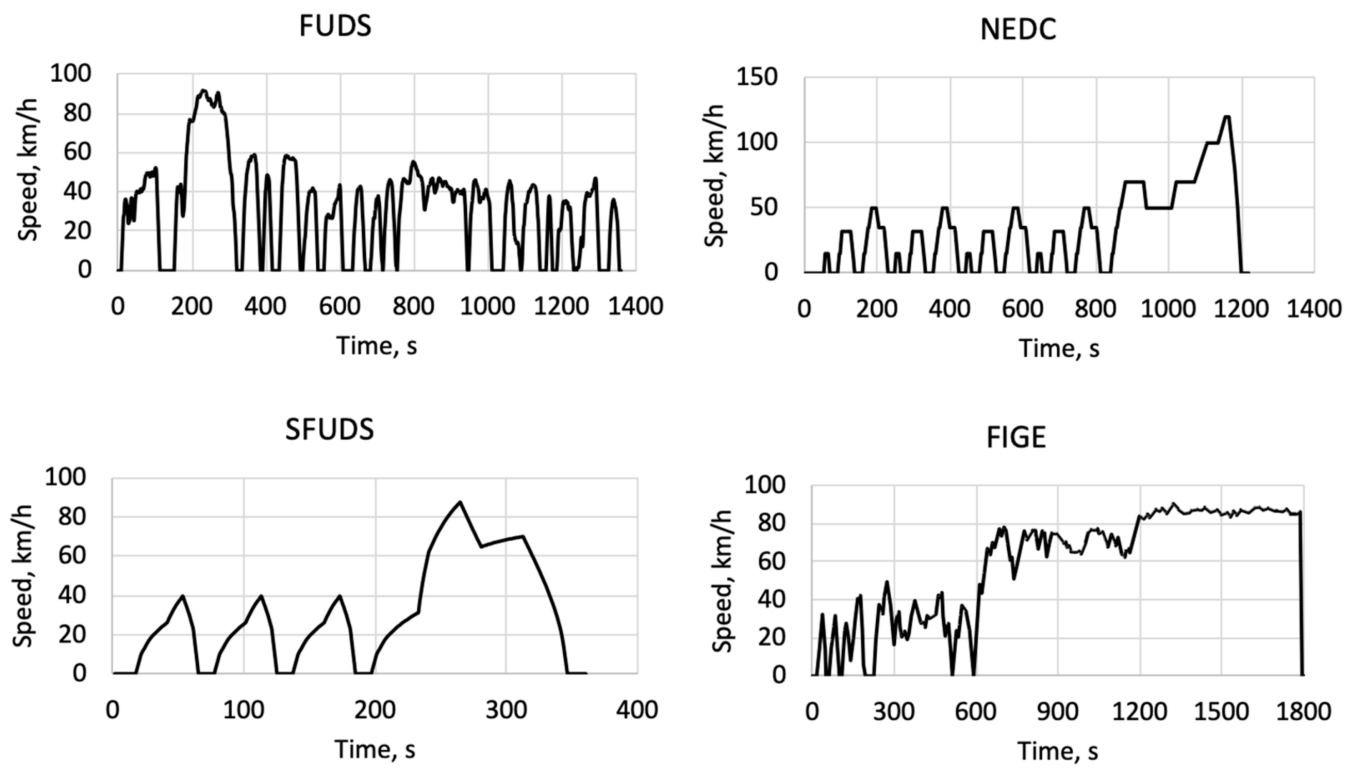

Figure 2. Driving cycles used for model validation.

The results of the validation are reported in Figure 3, showing the ranges obtained for each driving cycle versus the external ambient temperature. It can be noted that the range profiles obtained with FUDS, SFUDS, and NEDC are remarkably overlapped. This is mainly because of the similar urban nature of these cycles, characterized by almost the same value of the average speed. On the contrary, the FIGE cycle, where the urban conditions are representative of only one-third of the entire cycle time span (the average speed is in fact $59 \mathrm{~km} / \mathrm{h}$ ), has a driving range higher than the others by $20-25 \mathrm{~km}$.

In all the considered cases, the effect of accessories consumption due to cabin heating is remarkable. In the cases of FUDS, SFUDS, and NEDC, the range exceeds $150 \mathrm{~km}$ at $20^{\circ} \mathrm{C}$, while it reduces to about $85 \mathrm{~km}$ and $60 \mathrm{~km}$ at $0{ }^{\circ} \mathrm{C}$ and $-15^{\circ} \mathrm{C}$, respectively. In the case of FIGE, the range is $171 \mathrm{~km}$ at $20^{\circ} \mathrm{C}$, $122 \mathrm{~km}$ at $0{ }^{\circ} \mathrm{C}$, and $88 \mathrm{~km}$ at $-15^{\circ} \mathrm{C}$.

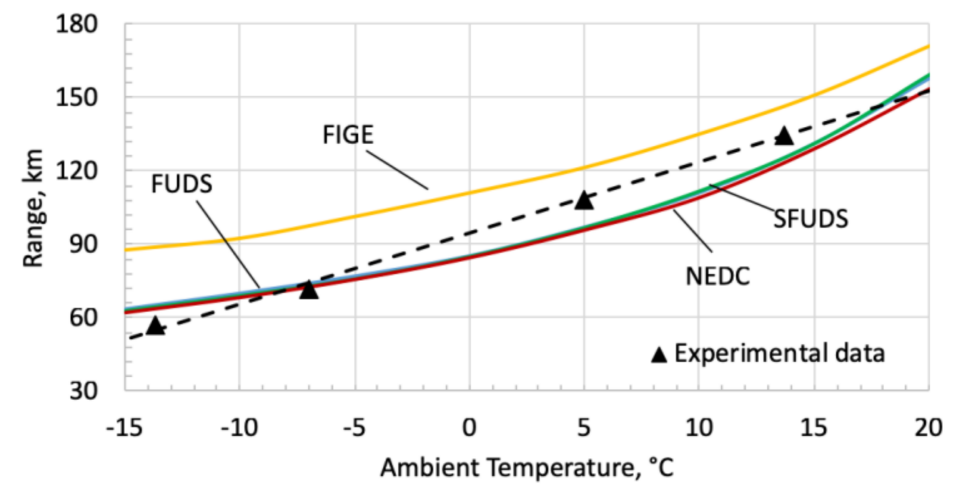

Figure 3. Results of the model validation.

\section{Sensitivity Analysis}

As shown in Table 1, several models can be found in the literature, specifically focused on reproducing the Nissan Leaf performances. These are based on a rather wide range of assumptions, which, in the present work, have been accurately analyzed and selected in order to best fit the experimental data employed for the validation (Figure 3). Furthermore, in order to better investigate the impact of such assumptions, a sensitivity analysis has been carried out on two key model parameters, namely the battery Peukert constant $k$ (Equation (10)) and the regenerative braking efficiency $\eta_{r b}$ (Equation (4)). 
As discussed in Section 2, the value of $k$ quantifies the discharge efficiency. In fact, according to the Peukert model as per Equation (11), for a supplied charge $I \Delta t$, the actual charge removed from the battery is $I^{k} \Delta t$. Values of $k$, according to the authors of [41], in the case of Li-ion batteries, typically vary in the range of 1.0-1.08. Figures 4-6 portray the driving range as a function of $k$ for the four driving cycles considered in this analysis at ambient temperatures of $20^{\circ} \mathrm{C}, 0{ }^{\circ} \mathrm{C}$, and $-15^{\circ} \mathrm{C}$, respectively. It can be noted that the impact of $k$ on range is appreciable, varying from about $5 \%$ to $20 \%$ depending on the driving cycle and ambient temperature, with the highest variation of $21 \%$ obtained in the case of FUDS cycle at $20^{\circ} \mathrm{C}$ (Figures 4-6).

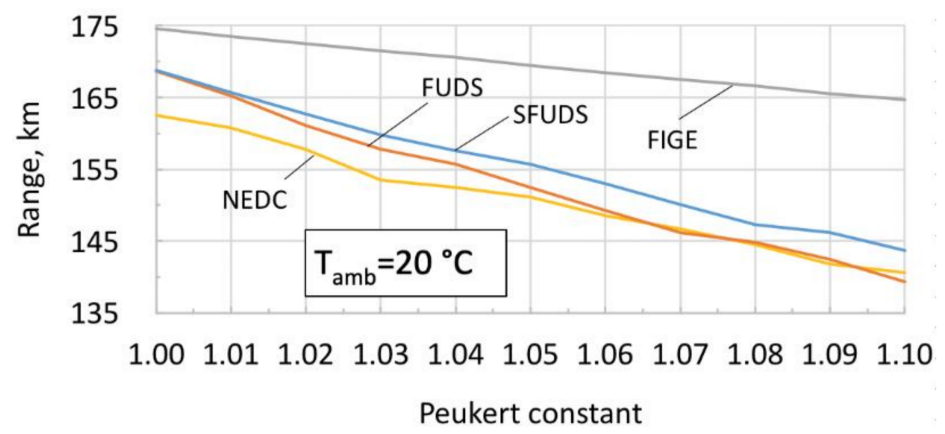

Figure 4. Driven range as a function of the Peukert constant $k$ in the case of ambient temperature of $20^{\circ} \mathrm{C}$.

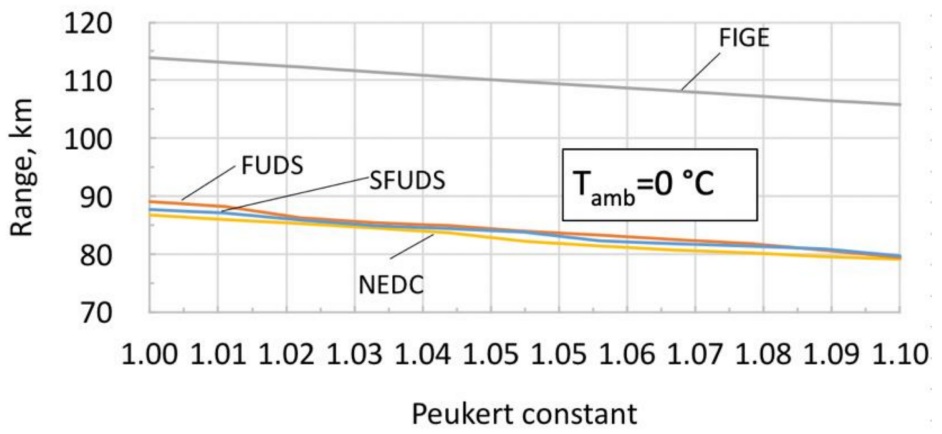

Figure 5. Driven range as function of the Peukert constant $k$ in the case of ambient temperature of $0{ }^{\circ} \mathrm{C}$.

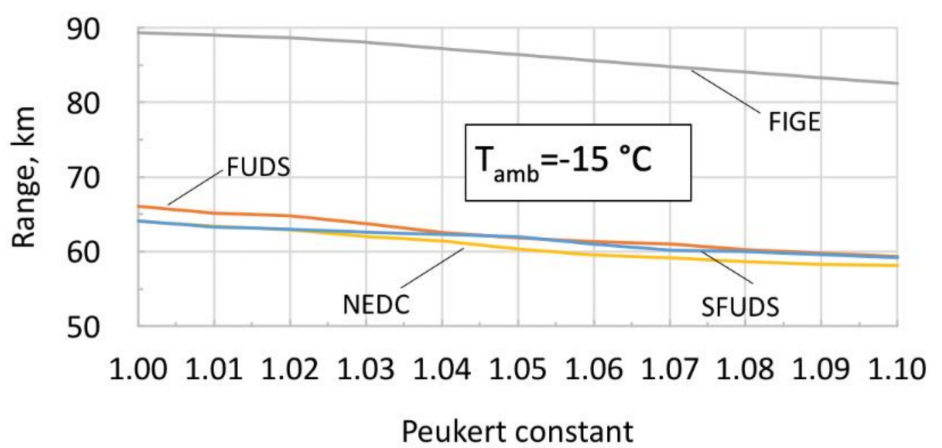

Figure 6. Driven range as function of the Peukert constant $k$ in the case of ambient temperature of $-15^{\circ} \mathrm{C}$.

Regarding the sensitivity analysis on the regenerative braking, the following cases have been considered:

(a) $\eta_{r b}=0$ : no braking power recovered, that is, the entire braking power is wasted by mechanical brakes.

(b) $\eta_{r b}=1$ : the whole braking power available at the wheels is converted into electricity according to the generator operating efficiency. 
(c) $\quad \eta_{r b}=\left[e^{\left(\frac{0.0411}{|a(t)|}\right)}\right]^{-1}$ according to the authors of [1]; this case has been also assumed as the reference case in the present model.

(d) $\eta_{r b}$ as a function of the vehicle speed according to the model proposed in the work of [37] and given by the following:

$$
\left\{\begin{array}{c}
\eta_{r b}=0 \text { if } v<5 \frac{\mathrm{km}}{\mathrm{h}} \\
\eta_{r b}=0.0834 v-0.417 \text { if } 5<v<17 \frac{\mathrm{km}}{\mathrm{h}} \\
\eta_{r b}=1 \text { if } v>17 \frac{\mathrm{km}}{\mathrm{h}}
\end{array}\right.
$$

In addition, the maximum recoverable braking power is subject to the driving/braking torque limitation of the electric motor/generator.

(e) Maximum regenerative power limited to $20 \mathrm{~kW}$ according to the authors of [38], that is, all the available regenerative power $P_{\text {Wheels }}$ is fed into the electric generator as long as its value does not exceed $20 \mathrm{~kW}$.

Cases from (a) to (e) have been simulated for all the driving cycles and the results are compared in Figures 7-11. It can be observed that in all the analyzed cases, the results obtained with the assumptions proposed in the work of [1,37] (case (c) and case (d), respectively) are very close to the assumption of case $(b)\left(\eta_{r b}=1\right)$. On the contrary, neglecting the contribution of the regenerative braking energy, as in case (a) $\left(\eta_{r b}=0\right)$, results in a significant reduction of the driving range. For instance, at an ambient temperature of $20^{\circ} \mathrm{C}$, the range reduces with respect to the reference case from $160 \mathrm{~km}$ to $120 \mathrm{~km}(-25 \%)$ in the case of SFUDS, from $158 \mathrm{~km}$ to $115 \mathrm{~km}(-27 \%)$ in the case of FUDS, from $154 \mathrm{~km}$ to $124 \mathrm{~km}(-20 \%)$ in the case of NEDC, and from $172 \mathrm{~km}$ to $160 \mathrm{~km}(-6 \%)$ in the case of FIGE.

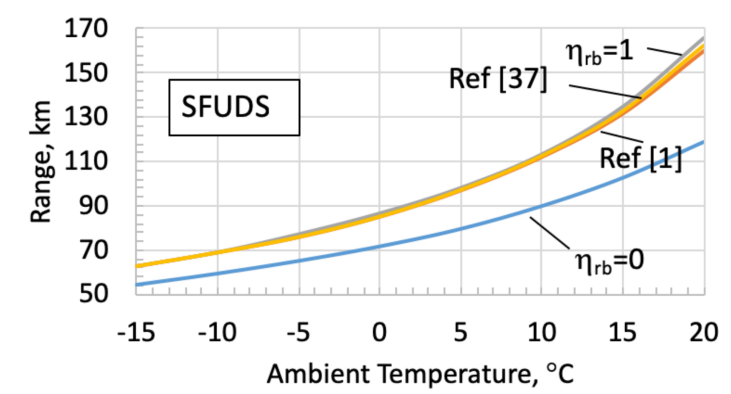

Figure 7. Impact of different regenerative braking assumptions on range in the case of SFUDS driving cycle.

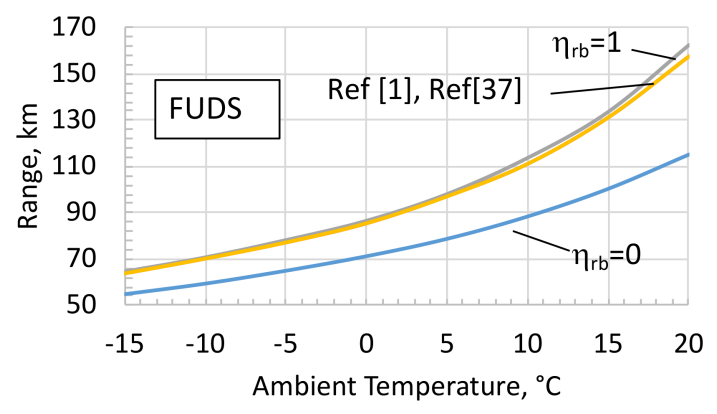

Figure 8. Impact of different regenerative braking assumptions on range in the case of FUDS driving cycle. 


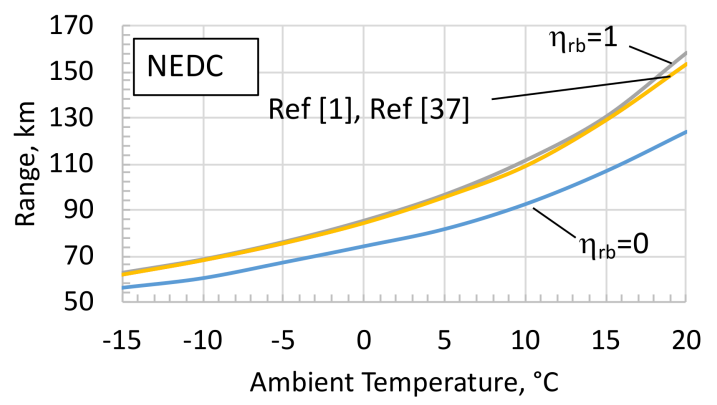

Figure 9. Impact of different regenerative braking assumptions on range in the case of NEDC driving cycle.

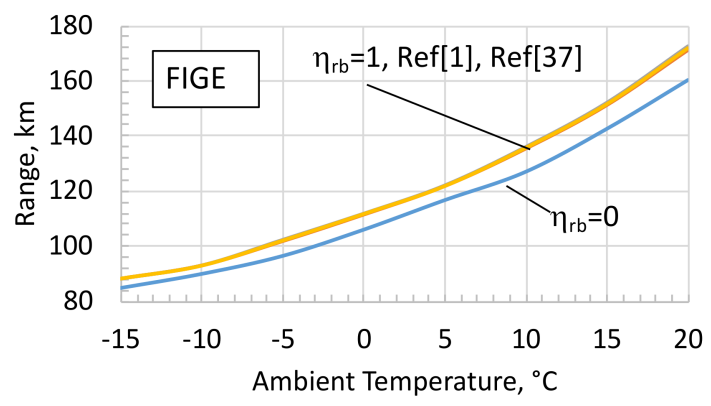

Figure 10. Impact of different regenerative braking assumptions on range in the case of FIGE driving cycle.

Finally, the effect of the assumption on the maximum regenerative power, case (e), is evidenced in Figure 11 for all the simulated driving cycles and an ambient temperature of $20^{\circ} \mathrm{C}$. Clearly, when this limit is $0 \mathrm{~kW}$, the results coincide with those obtained in case (a) with $\eta_{r b}=0$, while they reach asymptotically case (b) of $\eta_{r b}=1$ as the value of the limiting regenerative power increases. The black dashed line represents the hypothesis assumed in the work of [38] of a maximum regenerative power of $20 \mathrm{~kW}$. It can be observed that with FIGE and SFUDS driving cycles, the ranges obtained with case (e) are very close to case (b) $\eta_{r b}=1$, while the highest difference (about $5 \mathrm{~km}$ ) is observed only with NEDC.

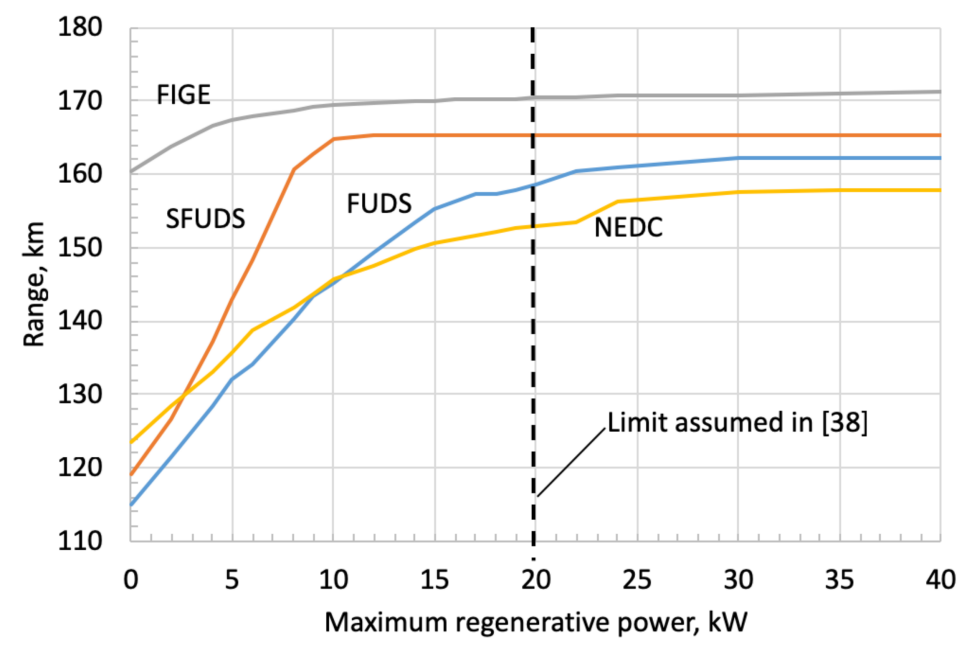

Figure 11. Driving range as a function of the limit on the maximum power for regenerative braking at $20{ }^{\circ} \mathrm{C}$. 


\section{Conclusions}

This paper presents a general BEV energy consumption model, based on a critical analysis of the main assumptions made in existing models, aiming at identifying the best compromise between accuracy and the possibility to build up a straightforward and effective tool for the simulation of commercial electric vehicles, whenever general operating data are publicly available. The model parameters were set up with the aim of reproducing the characteristics of the Nissan Leaf.

The model is validated on data recorded through the experimental campaign reported in the work of [27], where the Nissan Leaf was driven to depletion across a broad range of ambient temperatures occurring in Winnipeg, MB, Canada, during winter. The analysis aims at assessing the effect of the ambient temperature (in the range of $-15^{\circ} \mathrm{C} / 20^{\circ} \mathrm{C}$ ), due to the consequent accessory power required for cabin heating, on energy consumption and range. To this end, vehicle simulations are first carried out considering the FUDS $\left(v_{\max }=91 \mathrm{~km} / \mathrm{h}, v_{a v}=32 \mathrm{~km} / \mathrm{h}\right)$ and SFUDS $\left(v_{\max }=87 \mathrm{~km} / \mathrm{h}\right.$, $v_{a v}=31 \mathrm{~km} / \mathrm{h}$ ) driving cycles, showing a good agreement with the experimental data, with these cycles' features similar to those of the reference routes, particularly in terms of average and maximum speeds. The analysis was further extended to FIGE and NEDC cycles, thus also considering extra urban, rural, and motorway driving profiles.

The effect of the accessories consumption due to cabin heating as ambient temperature varies is remarkable. For instance, in the case of FUDS, SFUDS, and NEDC driving cycles, the range exceeds $150 \mathrm{~km}$ at $20^{\circ} \mathrm{C}$, while it reduces to about $85 \mathrm{~km}$ and $60 \mathrm{~km}$ at $0{ }^{\circ} \mathrm{C}$ and $-15^{\circ} \mathrm{C}$, respectively.

Finally, through a sensitivity analysis, the impact of two key model parameters, namely the battery Peukert constant $k$ and the regenerative braking efficiency $\eta_{r b}$, has been assessed. In particular, the results available in literature are found to be very close to the assumption of $\eta_{r b}=1$.

Future analyses will investigate the design, modelling, and application of more efficient cabin conditioning systems based on heat pumps coupled with innovative energy recovery devices in order to mitigate the range reduction occurring in the case of severe weather conditions.

Author Contributions: Equal contributions from both authors.

Funding: This research was funded by DIMI (University of Brescia) under the TEC (Tesla Expander Chiller) project.

Conflicts of Interest: The authors declare no conflict of interest.

\section{Abbreviations}

$\begin{array}{ll}\text { Notations } & \\ A & \text { Frontal area, } \mathrm{m}^{2} \\ a & \text { Acceleration, } \mathrm{m} / \mathrm{s}^{2} \\ \mathrm{BEV} & \text { Battery electric vehicle } \\ \mathrm{C} & \text { Battery capacity, Ah } \\ C_{d} & \text { Drag coefficient } \\ C_{p} & \text { Peukert capacity, Ah } \\ \Delta C R & \text { Removed/added charge, Ah } \\ E & \text { Open circuit voltage, V } \\ \text { FIGE } & \text { FIGE (Forschungsinstitut Geräusche und Erschütterungen) Institute, Aachen, Germany } \\ \text { FUDS } & \text { Federal Urban Driving Schedule } \\ G & \text { Gear ratio } \\ g & \text { Gravity acceleration, } \mathrm{m} / \mathrm{s}^{2} \\ \mathrm{HVAC} & \text { Heating, ventilation, and air-conditioning } \\ I & \text { Current, A } \\ k & \text { Peukert constant } \\ m_{\mathcal{C}} & \text { Vehicle mass with battery pack (curb weight), kg } \\ m_{I} & \text { Vehicle equivalent mass increase due to the angular moments of the rotating components } \\ m_{v} & \text { Total vehicle mass including occupants (gross weight), kg }\end{array}$




$\begin{array}{ll}\text { NEDC } & \text { New Eu } \\ P & \text { Power, } \mathrm{W} \\ R_{\text {int }} & \text { Battery internal resistance, } \Omega \\ \text { SFUDS } & \text { Simplified Federal Urban Driving Schedule } \\ \text { SOC } & \text { State of charge } \\ t & \text { Time, } \mathrm{t} \\ v & \text { Velocity, } \mathrm{m} / \mathrm{s} \\ \text { Subscripts } & \\ \text { Acc } & \text { Accessories } \\ \text { Bat } & \text { Battery } \\ \text { av } & \text { Average } \\ \text { max } & \text { Maximum } \\ i & \text { i-th time step } \\ \text { Greek symbols } & \\ \alpha & \text { Slope angle of the road } \\ \rho & \text { Air density, kg/m }{ }^{3} \\ \eta_{m} & \text { Electric motor } / \text { generator efficiency } \\ \eta_{r b} & \text { Regenerative braking efficiency } \\ \eta_{t r} & \text { Transmission and gear efficiency } \\ \mu_{r r} & \text { Rolling resistance coefficient }\end{array}$

\section{References}

1. Fiori, C.; Ahn, K.; Rakha, H.A. Power-based electric vehicle energy consumption model: Model development and validation. Appl. Energy 2016, 168, 257-268. [CrossRef]

2. Ehsani, M.; Gao, Y.; Emadi, A. Modern electric, hybrid electric, and fuel cell vehicles: Fundamentals, theory, and design. In Power Electronics and Applications Series, 2nd ed.; CRC Press: Boca Raton, FL, USA, 2010.

3. Tribioli, L.; Cozzolino, R.; Chiappini, D.; Iora, P. Influence of Fuel Type on the Performance of a Plug-In Fuel Cell/Battery Hybrid Vehicle with On-Board Fuel Processing. In SAE Technical Paper, Proceedings of SAE 13th International Conference on Engines and Vehicles, ICE 2017, Capri, Napoli, Italy, 10-14 September 2017.

4. Tribioli, L.; Cozzolino, R.; Chiappini, D.; Iora, P. Energy management of a plug-in fuel cell/battery hybrid vehicle with on-board fuel processing. Appl. Energy 2016, 184, 140-154. [CrossRef]

5. Wang, Z.; Ma, J.; Zhang, L. State-of-Health Estimation for Lithium-Ion Batteries Based on the Multi-Island Genetic Algorithm and the Gaussian Process Regression. IEEE Access 2017, 5, 21286-21295. [CrossRef]

6. Zhang, J.; Zhang, L.; Sun, F.; Wang, Z. An Overview on Thermal Safety Issues of Lithium-ion Batteries for Electric Vehicle Application. IEEE Access 2018, 6, 23848-23863. [CrossRef]

7. Chan, C.C. The state of the art of electric and hybrid vehicles. Proc. IEEE 2002, 90, 247-275. [CrossRef]

8. Lin, Z. Measuring Range Anxiety: The Substitution-Emergency-Detour (SED) Method. World Electr. Veh. J. 2012, 5, 8-13. [CrossRef]

9. Shareef, H.; Islam, M.M.; Mohamed, A. A review of the stage-of-the-art charging technologies, placement methodologies, and impacts of electric vehicles. Renew. Sustain. Energy Rev. 2016, 64, 403-420. [CrossRef]

10. Hidrue, M.K.; Parsons, G.R.; Kempton, W.; Gardner, M.P. Willingness to pay for electric vehicles and their attributes. Resour. Energy Econ. 2011, 33, 686-705. [CrossRef]

11. Baptista, P.; Pina, A.; Duarte, G.; Rolim, C.; Pereira, G.; Silva, C.; Farias, T. From on-road trial evaluation of electric and conventional bicycles to comparison with other urban transport modes: Case study in the city of Lisbon, Portugal. Energy Convers. Manag. 2015, 92, 10-18. [CrossRef]

12. Yagcitekin, B.; Uzunoglu, M.; Karakas, A.; Erdinc, O. Assessment of electrically-driven vehicles in terms of emission impacts and energy requirements: A case study for Istanbul, Turkey. J. Clean. Prod. 2015, 96, 486-492. [CrossRef]

13. Lv, C.; Zhang, J.; Li, Y.; Yuan, Y. Mechanism analysis and evaluation methodology of regenerative braking contribution to energy efficiency improvement of electrified vehicles. Energy Convers. Manag. 2015, 92, 469-482. [CrossRef] 
14. Pina, A.; Baptista, P.; Silva, C.; Ferrão, P. Energy reduction potential from the shift to electric vehicles: The Flores island case study. Energy Policy 2014, 67, 37-47. [CrossRef]

15. Baptista, P.; Silva, C.; Lopes, J.P.; Soares, F.; Almeida, P. Evaluation of the benefits of the introduction of electricity powered vehicles in an island. Energy Convers. Manag. 2013, 76, 541-553. [CrossRef]

16. Laurikko, J.; Granström, R.; Haakana, A. Realistic estimates of EV range based on extensive laboratory and field tests in Nordic climate conditions. World Electr. Veh. J. 2013, 6, 192-203. [CrossRef]

17. Lombardi, L.; Tribioli, L.; Cozzolino, R.; Bella, G. Comparative environmental assessment of conventional, electric, hybrid, and fuel cell powertrains based on LCA. Int. J. Life Cycle Assess. 2017, 22, 1989-2006. [CrossRef]

18. Qi, Z.; Yang, J.; Jia, R.; Wang, F. Investigating Real-World Energy Consumption of Electric Vehicles: A Case Study of Shanghai. Procedia Comput. Sci. 2018, 131,367-376. [CrossRef]

19. Yao, E.; Yang, Z.; Song, Y.; Zuo, T. Comparison of Electric Vehicle's Energy Consumption Factors for Different Road Types. Discret. Dyn. Nat. Soc. 2013, 2013, 328757. [CrossRef]

20. Fiori, C.; Ahn, K.; Rakha, H.A. Optimum routing of battery electric vehicles: Insights using empirical data and microsimulation. Transp. Res. Part D Transp. Environ. 2018, 64, 262-272. [CrossRef]

21. Maia, R.; Silva, M.; Araújo, R.; Nunes, U. Electric vehicle simulator for energy consumption studies in electric mobility systems. In Proceedings of the 2011 IEEE forum on integrated and sustainable transportation system (FISTS), Vienna, Austria, 29 June-1 July 2011; pp. 227-232.

22. Wu, X.; Freese, D.; Cabrera, A.; Kitch, W.A. Electric vehicles' energy consumption measurement and estimation. Transp. Res. Part D Transp. Environ. 2015, 34, 52-67. [CrossRef]

23. Shankar, R.; Marco, J. Method for estimating the energy consumption of electric vehicles and plug-in hybrid electric vehicles under real-world driving conditions. IET Intell. Transp. Syst. 2013, 7, 138-150. [CrossRef]

24. Bellocchi, S.; Guizzi, G.L.; Manno, M.; Salvatori, M.; Zaccagnini, A. Reversible heat pump HVAC system with regenerative heat exchanger for electric vehicles: Analysis of its impact on driving range. Appl. Therm. Eng. 2018, 129, 290-305. [CrossRef]

25. Zhou, G.; Li, H.; Liu, E.; Li, B.; Yan, Y.; Chen, T.; Chen, X. Experimental study on combined defrosting performance of heat pump air conditioning system for pure electric vehicle in low temperature. Appl. Therm. Eng. 2017, 116, 677-684. [CrossRef]

26. Kohei, U.; Noyama, H. Air-conditioning system for electric vehicles (i-MiEV). In Proceedings of the SAE Automotive Refrigerant \& System Efficiency Symposium, Scottsdale, AZ, USA, 13-15 July 2010; Volume 1.

27. Rizalino, J.; Reyes, M.D.; Parsons, R.V.; Hoemsen, R. Winter Happens: The Effect of Ambient Temperature on the Travel Range of Electric Vehicles. IEEE Trans. Veh. Technol. 2016, 65, 4016-4022.

28. Lowse-Busch, H.; Duoba, M.; Rask, E.; Meyer, M. Advanced Powertrain Research Facility AVTA Nissan Leaf Testing and Analysis; Argonne National Laboratory: Lemont, IL, USA, 2012.

29. Wongwises, S.; Kamboon, A.; Orachon, B. Experimental investigation of hydrocarbon mixtures to replace HFC-134a in an automotive air conditioning system. Energy Convers. Manag. 2006, 47, 1644-1659. [CrossRef]

30. Alves, J.; Baptista, P.C.; Gonçalves, G.A.; Duarte, G.O. Indirect methodologies to estimate energy use in vehicles: Application to battery electric vehicles. Energy Convers. Manag. 2016, 124, 116-129. [CrossRef]

31. Tian, Z.; Qian, C.; Gu, B.; Yang, L.; Liu, F. Electric vehicle air conditioning system performance prediction based on artificial neural network. Appl. Therm. Eng. 2015, 89, 101-114. [CrossRef]

32. Kambly, K.; Bradley, T.H. Geographical and temporal differences in electric vehicle range due to cabin conditioning energy consumption. J. Power Sources 2015, 275, 468-475. [CrossRef]

33. Hendricks, J.T. Vehicle Transient Air Conditioning Analysis: Model Development E System Optimization Investigations; National Renewable Energy Laboratory: Golden, CO, USA, 2001.

34. Farrington, R.; Rugh, P.J. Impact of Vehicle Air Conditioning on Fuel Economy, Tailpipe Emissions, and Electric Vehicle Range; NREL/CP-540e28960; National Renewable Energy Laboratory: Golden, CO, USA, 2000.

35. Sarrafan, K.; Sutanto, D.; Muttaqi, K.M.; Town, G. Accurate range estimation for an electric vehicle including changing environmental conditions and traction system efficiency. IET Electr. Syst. Transp. 2017, 7, 117-124. [CrossRef]

36. Larminie, J.; Lowry, J. Electric Vehicle Technology Explained; John Wiley \& Sons Ltd.: Chichester, UK, 2012.

37. Genikomsakis, K.N.; Mitrentsis, G. A computationally efficient simulation model for estimating energy consumption of electric vehicles in the context of route planning applications. Transp. Res. Part D Transp. Environ. 2017, 50, 98-118. [CrossRef] 
38. Davis, K.; Hayes, J.G. Simplified Electric Vehicle Powertrain Model for Range and Energy Consumption based on EPA Coast-down Parameters and Test Validation by Argonne National Lab Data on the Nissan Leaf. In Proceedings of the 2014 IEEE Transportation Electrification Conference and Expo: Components, Systems, and Power Electronics-From Technology to Business and Public Policy (ITEC 2014), Dearborn, MI, USA, 15-18 June 2014.

39. Davis, K.; Hayes, J.G. Analysis of Electric Vehicle Powertrain Simulators for Fuel Consumption Calculations. In Proceedings of the 2016 International Conference on Electrical Systems for Aircraft, Railway, Ship Propulsion and Road Vehicles and International Transportation Electrification Conference (ESARS-ITEC 2016), Railway, Toulouse, France, 2-4 November 2016.

40. Maia, R.; Silva, M.; Araújo, R.; Nunes, U. Electrical vehicle modeling: A fuzzy logic model for regenerative braking. Expert Syst. Appl. 2015, 42, 8504-8519. [CrossRef]

41. Omar, N.; Daowd, M.; van den Bossche, P.; Hegazy, O.; Smekens, J.; Coosemans, T.; van Mierlo, J. Rechargeable Energy Storage Systems for Plug-in Hybrid Electric Vehicles-Assessment of Electrical Characteristics. Energies 2012, 5, 2952-2988. [CrossRef]

42. Cell Module, and Pack for EV Application. Available online: http:/ /www.eco-aesc-lb.com/en/product/ liion_ev / (accessed on 25 October 2018).

43. Brandt, D.D. Driving cycle testing of electric vehicle batteries and systems. J. Power Sources 1992, 40, 73-79. [CrossRef]

(C) 2019 by the authors. Licensee MDPI, Basel, Switzerland. This article is an open access article distributed under the terms and conditions of the Creative Commons Attribution (CC BY) license (http://creativecommons.org/licenses/by/4.0/). 